\title{
Transição à democracia e os usos do passado recente para a legitimação de um novo regime político no México
}

Larissa Jacheta Riberti ${ }^{1}$

Resumo: Este artigo pretende debater o processo de transição à democracia no México à luz das mudanças políticas e institucionais e da atuação dos movimentos sociais que permitiram a vitória de Vicente Fox nas eleições 2000. Nesse sentido, serão discutidos dois aspectos centrais desse processo: as reformas políticas empreendidas a partir da década de 1970 pelos governos priistas e as lutas sociais configuradas desde pelo menos 1960 e que tenham sido capazes de repercutir as pressões pela democratização do Estado, pela mudança político-partidária e pelo deslinde de responsabilidades das violações cometidas nas décadas anteriores. Assim, busca-se apreender como o candidato à presidência de oposição fez uso das demandas por verdade, memória e justiça reivindicadas por organismos de direitos humanos e familiares de mortos e desaparecidos para construir uma plataforma política e uma coalização entre diferentes setores ideológicos em nome do tão esperado "giro político".

Palavras-chave: Transição à Democracia; Justiça Transicional; México

\section{Transition to democracy and the uses of the recent past to legitimize a new political regime in Mexico}

\begin{abstract}
This article aims at discussing the process of transition to democracy in Mexico in the light of political and institutional changes and the performance of social movements that allowed Vicente Fox to win in the 2000 presidential elections. In this sense, two central aspects of this process will be discussed: political reforms made by the priistas governments since the 1970s and the social struggles that have taken place since at least the 1960s that were able to pressure for the democratization of the State, for politicalparty changes and for the assignment of responsibilities for the humans rights violations committed in the previous decades. Besides that, we seek to understand how Fox made use of the demands for truth, memory and justice claimed by human rights and organizations and family members of deaths and missing persons, to build a political
\end{abstract}

\footnotetext{
${ }^{1}$ Profa. Dra. de História Contemporânea da Universidade Federal do Rio Grande do Norte, campus Caicó. Atualmente coordena o projeto de pesquisa "Surgimento e repressão do movimento armado socialista moderno no México entre as décadas de 1960 e 1980". Coorganizou o livro 1968. Perspectivas desde o tempo presente, lançado em 2020 pela Editora Letra e Voz. E-mail: larissa.riberti@gmail.com.
} 
platform and a coalition between different ideological sectors in the name of the "political turn".

Key words: Transition to Democracy; Transitional Justice; Mexico

Artigo recebido em: 02/07/2020

Artigo aprovado para publicação em: 19/10/2020

\section{Introdução ${ }^{2}$}

No México, o processo de transição à democracia e a luta social pela rendição de contas com um passado marcado por graves violações aos direitos humanos de lutadores sociais foram acompanhados de dois momentos fundamentais. O primeiro deles foi a vitória de Vicente Fox nas eleições presidenciais dos anos 2000. A escolha do candidato do Partido Acción Nacional ${ }^{3}$ para presidir o país encerrava 71 anos de sucessivos governos do Partido Revolucionário Institucional e, por isso, foi considerado por boa parte da historiografia que analisa esse processo - como veremos a seguir - o momento de consolidação desse processo de transição construído nas décadas anteriores.

Com uma história política bastante peculiar, o México distancia-se dos outros países da América Latina por não ter sido marcado por um golpe de Estado e pela instauração de uma ditadura militar. Apesar disso, a permanência do Partido Revolucionário Institucional no poder durante tantas décadas foi garantida com práticas políticas autoritárias, constantes fraudes eleitorais e sistemáticas perseguições à oposição política, principalmente após o governo de Lázaro Cárdenas.

Assim, não é exagerado dizer que o sistema político mexicano é o resultado de uma mistura entre o projeto partidário executado pelos representantes do PRI ao longo de quase um século e a própria noção de Estado. Vale destacar que o projeto priista para o país foi permeado de pretensões nacionalistas oriundas da Revolução Mexicana e, por meio de reformas populistas, barganhou direitos sociais e corporativizou espaços de luta

\footnotetext{
${ }^{2}$ Este artigo é derivado da minha tese de doutorado, defendida em 2017, e intitulada "Justiça de transição no México: as investigações jurídicas e o Informe Histórico da Fiscalía Especial para Movimientos Sociales y Políticos del Pasado (2001-2006)".

3 Em seu programa político, o PAN pode ser identificado como um partido de centro-direita. Ver: http://www.pan.org.mx/documentos-basicos/
} 
social importantes, como Sindicatos e Confederações de Trabalhadores. Além disso, a violência contra opositores políticos e a cooptação de lideranças de movimentos sociais foram recursos extensivamente utilizados pelos governos priistas para manter o monopólio do poder não apenas em nível presidencial, mas também nos governos estaduais e locais.

Vale destacar ainda que, no contexto da Guerra Fria e sob a influência do capitalismo imperialista, os dirigentes políticos mexicanos seguiram a cartilha do anticomunismo doutrinado pelo Estados Unidos no continente, apesar de que, em inúmeras ocasiões, bradou-se independência e autonomia nas tomadas de decisões (MEYER, 2004). Nesse sentido, a história desse país se aproxima a de tantos outros países que, no marco da Guerra Fria, forjaram mecanismos de controle, órgãos repressivos e institucionalizaram planos de contrainsurgencia, perseguiram partidos de oposição e de esquerda, cercearam liberdades e foram paulatinamente reprimindo lutadores sociais.

Por meio do aprofundamento e da sistematização de estratégias e mecanismos de repressão, os agentes dos governos priistas foram responsáveis por manchar o passado recente do país com gravíssimas violações aos direitos humanos daqueles que se opunham ao seu projeto político. Não seria possível elencar neste artigo a infeliz lista de episódios nos quais as forças policiais mexicanas reprimiram movimentos sociais e promoveram não apenas a prisão ilegal de dissidentes políticos, mas a tortura e, em muitos casos, o assassinato e o desaparecimento forçado de tais pessoas.

Mas vale destacar três episódios que representam bem esse processo de aprofundamento das práticas autoritárias e repressivas institucionalizadas desde o início dos governos do PRI. Um deles é o Massacre de Tlatelolco, ocorrido em 2 de outubro de 1968. O episódio, rememorado até hoje como um dos mais tristes da história mexicana recente, foi o trágico resultado de um plano governamental para reprimir e assassinar estudantes mobilizados contra o autoritarismo e por liberdades democráticas. Apenas três anos depois, em 11 de junho de 1971, um novo massacre de estudantes desencadeado no bairro Roma Norte, na cidade do México, posteriormente chamado de Jueves de Corpus (ou Halconazo), ratificou mais uma vez a incapacidade dos governos priistas de 
estabelecerem diálogos efetivos com as parcelas dissidentes dos estudantes e da juventude.

Por último, o PRI foi o responsável por sistematizar e ampliar as estratégias de contrainsurgência contra movimentos armados que configuraram o chamado Movimento Armado Moderno, surgido no país a partir de meados de 1960. A chamada "guerra suja", termo utilizado por grande parte da imprensa e de setores políticos e sociais para definir a época na qual se deu a confrontação do Estado contra a oposição armada, foi profundamente marcada pelas gravíssimas violações aos direitos humanos e, sobretudo, pela prática ostensiva do desaparecimento forçado pelos agentes da repressão e grupos paramilitares $^{4}$. É preciso destacar que existem controvérsias na aceitação da expressão "guerra suja" por parte de muitos pesquisadores do tema. $\mathrm{Na}$ análise que aqui nos interessa, no entanto, ela será utilizada porque remete à forma como oficialmente o Estado mexicano se referiu a esse período durante o processo de consolidação da transição e no qual essa questão foi amplamente debatida nos âmbitos civil e institucional.

O termo é utilizado na reconstrução histórica realizada pelo Informe publicado pela Fiscalía Especial para Movimientos Sociales y Políticos del Pasado (Femospp), em 2006. O organismo pretendeu ser um mecanismo de investigação dos casos de violações de direitos humanos, principalmente os desaparecimentos forçados de guerrilheiros, perpetrados por agentes do Estado entre fins de 1960 até meados de 1980. A criação da Femospp é precisamente o segundo momento que marca o processo de transição à democracia no México (RIBERTI, 2017).

Vale saber que o organismo surgiu em 27 de novembro de 2001, a partir de uma recomendação da Comisión Nacional de los Derechos Humanos (CNDH) ${ }^{5}$, o que representava um cumprimento de promessa de campanha de Vicente Fox. De seus discursos pré-eleitorais surgiu a ideia de conformar uma comissão da verdade, fruto

\footnotetext{
${ }^{4}$ De acordo com a pesquisadora Adela Cedillo (2008), a expressão foi sugerida por jornalistas mexicanos que, a partir da década de 1980, se apropriaram da terminologia utilizada no Cone Sul para denunciar situações irregulares de intervenção do exército contra as organizações guerrilheiras e civis.

5 A Recomendação 26/2001 foi formulada a partir das denúncias sobre pessoas desaparecidas recebidas desde 1990 pelo Programa Especial sobre Presuntos Desaparecidos (PREDES). Disponível: http://www.cndh.org.mx/ (verificado em junho de 2020)
} 
também da pressão por parte dos lutadores sociais, organismos de direitos humanos, familiares de vítimas e desaparecidos e sobreviventes daquele período chamado de "guerra suja" 6 . Na prática, no entanto, o presidente eleito decidiu pela criação de uma Fiscalía com caráter jurídico. Os motivos dessa mudança, que serão discutidos no tópico a seguir, revelaram posteriormente os acordos em nome da governabilidade e o abandono progressivo da pauta dos Direitos Humanos pelo governo recém-eleito.

Não cabe neste artigo discutir as atividades ou os resultados obtidos por processos e investigações instaurados no âmbito da Fiscalía Especial, os quais, é necessário destacar, não foram capazes de atribuir responsabilidades e deixaram pendentes as tarefas de promover justiça e imputar agentes políticos, policiais, militares e paramilitares pelas violações aos direitos humanos relatadas pelos sobreviventes e familiares de vítimas e desaparecidos políticos (RIBERTI, 2017).

Mas é preciso ressaltar que a existência da Femospp, cujas atividades foram encerradas em 2006, ainda é tema de controversas. O organismo, que deveria focar na investigação dos casos de desaparecimento forçado, acabou sofrendo uma série de mudanças em seu plano de trabalho, tendo incorporado, no início de 2002, a investigação do Massacre de Tlatelolco. A determinação, estabelecida pela Suprema Corte de Justiça, contrariou membros do Comitê 68 que, em 1998, abriram processo contra o Estado mexicano pela prática de genocídio naquele 2 de outubro. Os denunciantes não queriam que as investigações do caso fossem feitas pela Procuradoria Geral da República, órgão sob o qual estava subordinada a Fiscalía. Tal recusa se justificava pelo fato de que a PGR possuía um longo histórico de corrupção em seus processos de investigação e fracassos acumulados em outras tentativas de responsabilizar os culpados de violações aos direitos humanos.

A Femospp ainda incorporou outras investigações, tais como o Jueves de Corpus, de 1971, o caso Aguas Blancas, ocorrido em 1995, e o assassinato de 665 militantes e simpatizantes do Partido de la Revolución Democrática (PRD), eventos

\footnotetext{
${ }^{6}$ Fox também instruiu a criação de um Comité Ciudadano de Apoyo para contribuir nas investigações e, em janeiro de 2002, o Procurador Geral da República, Rafael Macedo de la Concha, nomeou o Dr. Ignacio Carrillo Prieto como Fiscal Especial (COMITÉ 68, 2008, Tomo X, p.137).
} 
ocorridos em 22 estados do país entre os anos de 1988 e 2001 (TREVIÑO-RANGEL, 2014). Essas investigações jurídicas e históricas nunca foram concluídas e nenhum desses casos levou ao julgamento ou punição dos responsáveis.

Ao longo de sua existência, a Fiscalía sofreu reveses em seu processo investigativo, esbarrou em uma série de obstáculos jurídicos e em uma estrutura política pouco comprometida em reformar as instituições e leis que pudessem garantir a aplicação do direito internacional humanitário. Em linhas gerais, as tentativas de responsabilização não conseguiram se enquadrar em tipificações internacionais de crimes de lesa humanidade e os casos sofreram prescrição por serem tratados como crimes comuns ${ }^{7}$.

No entanto, os trabalhos desenvolvidos pela Femospp e o impacto social de sua existência são muito mais complexos e não teríamos espaço para trata-los aqui. Vale pontuar, enfim, que o produto final da Fiscalía Especial foi o Informe Histórico Presentado a la Sociedad Mexicana, um documento fruto de disputas entre os colaboradores da área de investigação histórica, o Fiscal Ignacio Carrillo Prieto, acusado de manipular a versão final do informe, e a presidência da República ${ }^{8}$. A "novela" em torno da publicação do documento envolve o caso da filtração de sua versão preliminar à imprensa mexicana e ao National Archive Security, dos Estados Unidos ${ }^{9}$. Além disso, as disputas resultaram na conformação de um informe extraoficial intitulada "La Verdade Negada" (2012), publicado por organismos de direitos humanos e ex-colaboradores da Femospp que, até hoje, acusam o Fiscal e a PGR de terem censurado partes do documento

\footnotetext{
${ }^{7}$ Vale destacar o caso Rosendo Radilla Pacheco, desaparecido por efetivos do exército em agosto de 1974, e que foi levado à Corte Interamericana de Direitos Humanos em 2012 por seus familiares. A alegação do processo foi feita com base no Informe Histórico e nas investigações desenvolvidas pela Femospp. A aceitação dos documentos e da narrativa construída pelo Informe por parte da Corte resultou na histórica responsabilização do Estado mexicano pelo desaparecimento de Rosendo. Ver em RIBERTI, 2017, p.265.

${ }^{8}$ Uma discussão mais aprofundada dessa questão pode ser vista no capítulo "Verdade e justiça: as investigações jurídicas e as disputas pela verdade nos Informes da Fiscalía" (RIBERTI, 2017).

9 Ver em: NSA. Informe Documenta sobre 18 años de "Guerra Sucia" en México. "Fiscal Especial: Responsabilidad del Estado en Cientos de Asesinatos y Desapariciones Informe". Estados Unidos: 26 de fevereiro de 2006. Disponível em: http://www2.gwu.edu/ nsarchiv/NSAEBB/NSAEBB180/index2.htm (verificado em junho de 2020).
} 
original entregue pelas equipes de trabalho em dezembro de 2005 à Carrillo Prieto (RIBERTI, 2017, p. 190).

Considerando o anteriormente exposto, este artigo pretende debater o processo de transição à democracia no México à luz das mudanças políticas e institucionais e da atuação dos movimentos sociais que permitiram a eleição de Vicente Fox nos anos 2000. Nesse sentido, serão discutidos dois aspectos centrais desse processo: as mudanças institucionais e as reformas políticas empreendidas a partir da década de 1970 pelos governos priistas, e as lutas sociais configuradas desde pelo menos 1960 e que foram capazes de repercutir as pressões em torno da democratização do Estado, da mudança político-partidária e pelo deslinde de responsabilidades das violações cometidas nas décadas anteriores.

Vale alertar que o processo que culmina na transição (ou alternância de poder, como preferem alguns intérpretes), não é linear e homogêneo, mas marcado por muitas rupturas e significados, além de avanços e retrocessos no que se refere particularmente às decisões institucionais que tocam a questão da democracia, da cidadania e dos direitos humanos. Em muitos momentos, as ações que configuraram uma "abertura" da estrutura hegemônica priista podem ser lidas como respostas as crescentes pressões expressas por movimentos sociais ao longo das últimas décadas do século XX. Por outro lado, em muitas ocasiões o governo buscou estratégias para permanecer no poder e, portanto, constituir uma "fachada" supostamente flexível aos novos pleitos da sociedade. Em se tratando dos fenômenos sociais do período, é preciso atenção para não entendê-los como um conjunto de ações necessariamente interligadas e cujas demandas eram exatamente as mesmas. É preciso ter em mente que as últimas décadas do século XX foram marcadas por um amplo arcabouço de movimentos que manifestaram pautas, agendas e demandas ora convergentes, ora totalmente distintas.

Por fim, busca-se também neste artigo apreender como o candidato à presidência Vicente Fox fez uso das demandas por verdade, memória e justiça reivindicadas por organismos de direitos humanos e familiares de mortos e desaparecidos para construir uma plataforma política e uma coalização entre diferentes setores ideológicos em nome 
do tão esperado "giro político". Ao longo da discussão, será abordada de maneira complementar a criação da já citada Fiscalía Especial, enquanto mecanismo de justiça transicional vinculado à tal contexto.

\section{A transição democrática mexicana a partir das mudanças políticas e institucionais das últimas décadas}

Boa parte da bibliografia produzida sobre o longo período conhecido como "transição democrática" no México mostra que não existe um consenso entre os analistas sobre quando esse processo histórico começou, muito menos se ele acabou, se foi interrompido pelo retorno do PRI à presidência em 2012, ou se segue inconcluso.

Para Sergio Aguayo (2011), por exemplo, a transição democrática no país pode ser identificada a partir de 1963, quando da realização de uma reforma eleitoral e porque desde então houve uma diversificação nas formas de protesto que exigiam modificações nas regras de ocupação dos cargos públicos. A mudança citada pelo autor teve como objetivo, portanto, pluralizar, ainda que com resultados pouco significativos, a ocupação da Câmara dos Deputados, a fim de permitir a ocupação proporcional de candidatos de partidos de oposição ao Partido Revolucionário Institucional ${ }^{10}$.

Porém, de acordo com Balbuena Serrano (2005), a reforma criou um sistema de pseudo-representação proporcional, já que havia manipulação das listas plurinominais, o que deixava os partidos de oposição em condições desfavoráveis. Nessa perspectiva, a reforma foi pouco efetiva na diversificação daqueles que ocupavam os espaços legislativos, refletindo um processo que levaria décadas para promover uma mudança efetiva em termos de representação política.

\footnotetext{
${ }^{10}$ A nova regra determinou que todo partido nacional que obtivesse $2,5 \%$ dos votos em escala nacional tivesse direito a cinco cadeiras e uma cadeira a mais por cada $0,5 \%$ sucessivo de votos obtidos, com um total de 20 cadeiras, ocupadas então pelos chamados "deputados de partido ou plurinominais". Por outro lado, os deputados da maioria alcançavam necessariamente o número de 20 cadeiras. A Ley de Reforma del Sistema Electoral de 1963 está disponível em: http://www.dof.gob.mx/index.php?year=1963\&month=12\&day=28 (verificado em junho de 2020).
} 
A grande maioria dos analistas da transição mexicana entende que o movimento estudantil de 1968 foi o principal catalizador social de algumas reformas realizadas ao partir da década de 1970, pelo governo do presidente Luís Echeverría. A luta estudantil passou a ser vista como o detonador de um giro na cultura política do país, tendo, de acordo com Gilberto Guevara Niebla (2008), impulsionado não só as mudanças de orientação "populista" no governo Echeverría como também os rumos dos movimentos sociais posteriores que, da luta legal, passaram ao emprego das armas ${ }^{11}$.

Nessa mesma corrente de intepretação, Soledad Loaeza (1989) argumenta que a transição democrática é tributária das lutas de 1968 porque foi essa explosão social que permitiu a reforma do sistema político que culminou na alternância de regime em 2000. O movimento estudantil influenciou percepções, comportamentos e decisões políticas de tal maneira que determinou as mudanças nas décadas seguintes (1989, p.69). Para Loaeza, o movimento foi incorporado por uma "interpretação dominante" desde as estruturas políticas que, em vez de rechaçar sua luta democrática, o assimilou na história do processo democrático, ainda que tal assimilação não fosse reconhecida por parte dos antigos participantes do movimento.

Assim, a luta estudantil de 1968 e seu trágico desenlace, o Massacre de Tlatelolco de 2 de outubro, foram sendo paulatinamente recuperados pela "história oficial" a partir da década de 1970. Os representantes do priismo, que, na maioria dos casos, costumavam tratar os movimentos de oposição à hegemonia do partido como "inimigos", passaram a identificar-se como "herdeiros" do movimento estudantil de 1968 e de sua luta pela democratização do Estado.

(...) En 1968 los estudiantes mexicanos desnudaron con tanta eficacia y casi naturalidad el autoritarismo, hasta entonces revestido de crecimiento económico y de conformismo, que su movilización fue un primer paso hacia el desmantelamiento de uno de los aspectos centrales de este régimen: la no participación. (...) (LOAEZA, 1989, p.71)

\footnotetext{
${ }^{11}$ Não existe consenso sobre as razões que detonaram e amplificaram o Movimento Armado Moderno no México. Sobre o assunto, ver: CEDILLO, 2008; VICENTE OVALLE, 2019; CASTELLANOS, 2007.
} 
Um dos exemplos de como o caráter "propulsor" da transição mexicana do movimento estudantil de 1968 foi incorporado pelas classes políticas pode ser identificado no marco do $45^{\circ}$ aniversário do movimento. Na ocasião, em 2013, Miguel Barbosa Huerta, coordenador parlamentário do Partido da Revolução Democrática ${ }^{12}$ no Senado mexicano, declarou publicamente que o movimento estudantil de 1968 marcou o início da transição democrática no país porque pela primeira vez um setor da sociedade havia realizado uma crítica frontal ao regime priista (VOCERO, 2013). Para Huerta, o movimento desencadeado em 1968 teve como foco a liberdade, o que questionou o autoritarismo por meio de estratégias de luta pacífica.

Pablo Gómez, ex-militante do movimento estudantil e então senador pelo PRD, defendeu em publicação em seu site que a maior parte dos avanços relacionados aos direitos fundamentais, assim como outras liberdades de caráter político, se devem à "luta democrática da juventude intelectual” (2014). Segundo ele, o movimento de 1968 não pode ser resumido às demandas formalizadas e publicadas por meio do pliego petitorio pelo Conselho Nacional de Greve. A luta daquele momento reivindicava liberdades e democracia em seus sentidos mais amplos. Além disso, o pedido pelo diálogo público com o governo, uma das bandeiras da época, era uma necessidade política que questionava o autoritarismo e a forma arbitrária de atuar do regime priista. (GOMES, 2018).

Nesse sentido, é possível observar que décadas depois do movimento estudantil de 1968, existe no México uma classe política que reivindica a luta daquele momento como impulsionadora do processo de transição. Mais que isso, essa classe política se diz "herdeira" das demandas e da mobilização reprimida pelo antigo regime do PRI.

Após a fissura causada pela repressão ao movimento estudantil de 1968, em especial o já citado Massacre de Tlatelolco, que expôs a imagem supostamente democrática do governo ao escrutínio da imprensa internacional presente na Cidade do México para a abertura dos Jogos Olímpicos daquele ano, a estratégia do novo presidente

\footnotetext{
12 O PRD foi criado em fins de 1980 como uma "alternativa à esquerda" e incorporou ex-guerrilheiros e militantes advindos de outros movimentos sociais (GONZÁLEZ, 2005).
} 
Luís Echeverría (1970-1976) consistiu em criar um ambiente no qual ele supostamente rechaçaria a herança deixada pelo antecessor, Gustavo Díaz Ordaz, e criaria condições para uma "abertura política". Projetou, portanto, uma autoimagem supostamente "progressista" e ofereceu "espaços" para conseguir negociar com a dissidência: estudantes secundaristas, intelectualidade e esquerda universitária (CEDILLO, 2008, p.143).

Para confirmar o distanciamento em relação ao governo anterior, Echeverría liberou os presos políticos de 1968 um ano depois de assumir a presidência. A medida, no entanto, teve caráter limitado, visto que os estudantes continuaram respondendo a processos por parte do Estado, acusados de violência, destruição de patrimônio público e de delito de dissolução social ${ }^{13}$. Os ex-líderes de 1968 só foram definitivamente liberados de tais processos em 1976, quando Luís Echeverría sancionou a Lei de Anistia ${ }^{14}$.

Na visão de Adela Cedillo (2008), o governo de Echeverría deu provas de que o espaço político estava aberto àqueles que estivessem dispostos a negociar alianças, apoios e alinhamentos às novas condições do pacto político (p. 145). Com isso, se por um lado o governo teria impulsionado o processo de transição democrática tomando como ponto de partida as reivindicações dos estudantes vítimas do massacre em 1968, por outro lado, iniciou uma política para reforçar seu nacionalismo econômico, adquirindo traços de populismo ou neopopulismo (REYNA, 2006).

No âmbito real, o novo governo resultou em mais retrocessos que avanços. Ao final do mandato de Echeverría, o México vivia uma crise econômica causada por quedas na produção agrícola, monopólio da indústria e greves trabalhistas. Em 1975, o

\footnotetext{
${ }^{13}$ Decretada em 30 de outubro de 1941, a Ley de Disolución Social integrou o Código Penal Federal e determinava prisão de dois a seis anos ao estrangeiro ou nacional mexicano que de forma falada ou escrita, bem como qualquer outro meio, realizasse propaganda política difundindo ideias, programas ou normas de ação de qualquer governo estrangeiro que perturbasse a ordem pública e afetasse a soberania nacional, tentando produzir rebelião, sedição ou motim. Tal lei foi um dos principais instrumentos jurídicos que integraram o aparato de repressão e perseguição aos membros de movimentos sociais opositores ao regime priista. (FISCALÍA ESPECIAL, 2008, p.56).

${ }^{14}$ A lei é composta de apenas dois artigos, sendo que o primeiro determina aplicação da anistia para pessoas contra as quais se moveu ação penal pelos crimes de sedição e incitação à rebelião no âmbito federal e por resistência de particulares no foro comum do Distrito Federal, assim como por delitos conexos aos anteriores, cometidos durante o conflito de 1968. Disponível em: http://www.dof.gob.mx/nota detalle.php?codigo=4845287\&fecha=20/05/1976 (verificado em 18 de outubro de 2020)
} 
subemprego chegou a atingir $45 \%$ da população economicamente ativa (CAMÍN e MEYER, 2000, p.272). No plano político, as contradições aumentavam ainda mais com uma doutrina que consistia em eliminar a esquerda do país e, consequentemente, a influência comunista, mas que ao mesmo tempo mantinha estreitas relações com dirigentes como Fidel Castro, Salvador Allende e Yasser Arafat (idem, ibidem).

Soma-se a isso a intensa perseguição aos membros de movimentos guerrilheiros e a utilização de estratégias de contrainsurgência para a eliminação de grupos dissidentes. Nesse sentido, Echeverría não foi apenas cúmplice no plano de repressão levado à cabo em 2 de outubro de 1968 durante a presidência de Diaz Ordaz ${ }^{15}$, mas foi o arquiteto das estratégias repressivas dos anos seguintes e responsável pelas violações aos direitos humanos de milhares de pessoas por todo o país durante seu mandato presidencial.

De acordo com o Informe Histórico da Femospp (2006), o mandato de Luís Echeverría foi marcado pela intensificação de conflitos entre movimentos guerrilheiros e as forças armadas, além da sistematização de estratégias repressivas e violadoras utilizadas pelos agentes do Estado. O Informe destaca que a partir de 1973, o exército passou a praticar "violações cada vez mais graves aos direitos humanos e ao direito humanitário" (p.621), escalando as práticas de contrainsurgência e transformando-as em uma política de violações ao direito humanitário internacional. Naquele momento foi registrado o maior número de desaparecimentos na história do país, tendo sido no estado de Guerrero o lugar onde mais ocorreram as detenções ilegais seguidas de desaparecimento (p.372-373).

Considerando tal contexto de "guerra suja", Adela Cedillo (2008) considera, ao contrário da maioria dos observadores que veem em 1968 a principal causa das reformas políticas posteriores, que o detonador definitivo da hegemonia do sistema político priista foi o conjunto de ações empreendidas pelo movimento armado socialista da década de

${ }^{15}$ Em 1968, Echeverría era Secretário de Governo e encarregado da segurança naquele contexto de realização de Jogos Olímpicos. Sua participação como idealizador e executor da chamada "Operação Galeana", que culminou no Massacre de Tlatelolco, foi comprovada a partir de documentos do general Marcelino García Barragán, analisados pelos pesquisadores Julio Scherer García e Carlos Monsiváis (1999). Com o processo de abertura de arquivos da Secretária de Governo e da Direção Federal de Segurança, iniciado em fins da década de 1990, a participação de Echeverría em planos de contrainsurgência e perseguição aos movimentos sociais foi novamente confirmada e ampliada. (GARCÍA, MONSIVÁIS, 1999). 
1970. Tal processo foi fundamental para estimular a realização de mudanças estruturais que configuraram, na visão da autora, a transição à democracia no país.

Uma delas foi a criação da Ley Federal de Organizaciones Políticas y Procesos Electorales (LOPPE), de 1977, durante o mandato de José Lopez Portillo, por meio da qual os partidos políticos poderiam conseguir registro legal e definitivo. Com a nova regra ficava a cargo da Comissão Federal Eleitoral analisar a documentação dos partidos demandantes de registro, o que lhes dava maiores chances de consegui-lo que com o processo anterior, organizado pela Secretaria de Governo, organismo aparelhado pelo PRI e que respondia diretamente aos interesses da presidência da república (TORRES, 2012).

Além disso, a reforma política deu novas regras ao processo eleitoral por meio do "registro condicionado", uma oportunidade para que outros partidos ingressarem na disputa eleitoral com a condição de que obtivessem 1,5\% da votação nas eleições, demonstrassem organização, atividade política prévia e definição ideológica (RAMÍREZ, 2002). Houve também ampliação e modificação na Câmara dos Deputados que, a partir de 1977, passava a ter 400 deputados, 300 deles eleitos por meio dos distritos eleitorais por maioria relativa, "mais 100 deputados pluri-nominais que seriam representados através de listas regionais por partidos e distribuir-se-iam na proporção às porcentagens de votação"16.

As estratégias econômicas e políticas para a garantia da hegemonia política surtiriam efeitos negativos dentro do próprio PRI. Ao final do mandato de Miguel de la Madrid (1983-1988), alguns setores internos passaram a exigir a "democratização" do partido. Assim, surgiu a chamada "Corrente Democrática", encabeçada por Cuauhtémoc Cárdenas, Porfírio Muñoz Ledo (ambos representantes de setores populistas e socialdemocratas) e outros críticos. A elite governamental que formou essa nova corrente buscava, entre outras mudanças, uma política estatal de gestão da crise vivida pelo país que se caracterizava pelo alto índice de desemprego, queda no salário real e dívida

\footnotetext{
${ }^{16}$ Adriana Sanchez (2002, p. 27-28) destaca que na primeira legislatura formada após as novas regras (19791982), a Câmara passou a ser composta por outros partidos além do PRI e PAN, como Partido Comunista Mexicano (PCM), Partido Revolucionario de los Trabajadores (PRT), e o Partido Mexicano de los Trabajadores (PMT). Apesar disso, porém, o PRI assegurou hegemonia dentro do legislativo.
} 
externa. A estratégia dessa nova corrente foi aliar-se a partidos de esquerda, o que resultou, segundo Adriana Sanchez (2002), no "primeiro movimento político importante de massas dos últimos 30 anos, o qual não se apresentava desde o movimento estudantil de 1968" (p. 32).

Devido a uma série de embates com a antiga direção do partido e as campanhas de intolerância frente à nova tendência, a Corrente Democrática resolveu competir nas eleições de 1988 organizando a Frente Democrática Nacional - que posteriormente se transformou no já citado Partido Revolucionário Democrático (PRD) - e lançando como candidato Cuauhtemóc Cárdenas, quem disputaria o cargo de presidente com Carlos Salinas de Gortari (PRI) e com Manuel Clouthier, do Partido Ação Nacional. Após as eleições, os resultados deram a vitória ao candidato priísta sob a justificativa de uma suposta queda no sistema de cômputo, o que, na verdade, ficou configurado como a maior fraude eleitoral do país das últimas décadas.

Em decorrência das fraturas internas do partido e da crise impulsionada pela fraude, modificações importantes no sistema eleitoral foram conduzidas a partir dos anos 1990, como a criação do Tribunal Federal Eleitoral (TRIFE) e do Instituto Federal Eleitoral (IFE), que substituiu a Comissão Federal Eleitoral. A reforma seguinte se deu em 1994 e alterou os critérios do quadro de dirigentes do IFE. No entanto, o organismo só conseguiu autonomia em relação ao poder executivo em 1996, após uma nova restruturação (TORRES, 2012). Assim, oito conselheiros eleitorais (indicados pelos partidos e referendados pela Câmara dos Deputados) e um conselheiro presidente formam seu conselho dirigente. O TRIFE também conquistou autonomia, pois foi incorporado ao Poder Judicial da Federação, que lhe concedeu autonomia para organizar todas as eleições, inclusive para presidente da república (TORRES, 2012).

Em função dessas alterações institucionais e políticas, Jose Woldenberg (2012) analisa que, entre 1977 e 1997, o México viveu uma "autêntica transição democrática". Para o autor, o período não reflete apenas uma mudança de caráter eleitoral, mas uma transformação no espaço da representação que resultou na "desconstrução de um regime autoritário quase "monopartidário". 
Vale destacar que em relação aos outros países da América Latina e da Europa que também vivenciaram transições à democracia, o México guarda duas especificidades. De acordo com Woldenberg (2012, p.15), a primeira delas é que não se viveu no país um golpe militar, nem uma ditadura, mas um regime estabelecido com práticas autoritárias para assegurar a hegemonia de um partido. Para isso, utilizou-se, como já abordado, uma série de instrumentos legais e ilegais para impedir a pluralidade político-partidária e para a cooptação e repressão dos movimentos sociais. Em segundo lugar, o processo vivido no México não resultou na formulação de uma nova constituição. Esse último fato se explica porque a constituição vigente desde 1917 era considerada um marco da república democrática, representativa e federal, amplamente aceita entre os setores sociais (p.14).

Esse ciclo de transformações iniciado em 1970 teve como consequência um processo de liberalização e de divisão do poder no qual o legislativo e o judiciário, tanto tempo declinados à hegemonia do poder executivo, passaram a ter relativa autonomia e independência (FAVELA, 2010, p.119). Na visão da autora, no entanto, é preciso considerar que, por mais que os movimentos sociais das últimas décadas do século XX tivessem exercido importante e forte pressão sobre os governos do PRI, as mudanças que iniciaram o processo de alternância política partiram do próprio governo que, ao ver sua hegemonia à beira do abismo, mudou as regras do jogo e as estratégias para negociar sua permanência no poder.

Ao analisar a historiografia que debate a transição no México, portanto, é evidente que grande parte dos intérpretes desse processo, ainda que não concordem sobre o momento em que ele se inicia, atribuem ao movimento estudantil de 1968 um protagonismo inquestionável enquanto propulsor de reformas importantes na década de 1970, e que foram fundamentais para a alternância que se configurou nos anos 2000. Tais reformas, sobretudo a eleitoral de 1977, são interpretadas à luz das consequências políticas do movimento de 1968 e da repressão estatal sofrida por ele, o que marcou toda uma geração política e social com o trauma do Massacre de Tlatelolco.

Surpreendentemente, ao se debruçarem sobre o amplo arcabouço de movimentos sociais que se desdobram sobretudo a partir da década de 1960 em oposição ao sistema 
priista, as análises dessa historiografia não atribuem o mesmo protagonismo ao movimento armado socialista nesse processo. O conjunto de movimentos guerrilheiros que existiu entre as décadas de 1960 e 1980 configurou um importante período de sublevações sociais tanto nas zonas rurais quanto urbanas (CASTELLANOS, 2007). Com diferentes propostas e formas de ação, tais movimentos não apenas se opunham à permanência do PRI no poder, mas alguns deles, a exemplo da Liga Comunista 23 de Septiembre, pleiteavam a derrocada do sistema e a implantação de um novo modelo de governo socialista.

A dimensão política de tais movimentos, apesar de negada reiteradamente pelos veículos de imprensa controlados pelos governos priistas e pelas narrativas oficiais, foi bastante significativa para a história recente do país (MUÑOZ, 2012). Nas décadas posteriores à experiência armada, muitos dissidentes políticos, ex-guerrilheiros e intelectuais de esquerda aderiram à tarefa de construir novos espaços de atuação institucional. Desse esforço coletivo resultou, por exemplo, o surgimento do Partido da Revolução Democrática que, ao longo do processo de transição, foi um dos principais opositores do PRI e demandante de transformações em nome da democracia.

Além disso, a luta desses movimentos armados avançou na discussão sobre a necessidade de questionar não só o autoritarismo de Estado, mas de subverter os mecanismos capitalistas de opressão das classes trabalhadoras urbanas e rurais, tendo inspirado posteriormente novos levantes como o do Exército Zapatista de Libertação Nacional, em 1994 (MONTEMAYOR, 1998). Nesse interim das décadas de 1960 e 1980, a experiência social resultou também no aparecimento de inúmeras organizações em defesa dos direitos humanos e de familiares de mortos e desaparecidos, além de vítimas sobreviventes, protagonistas fundamentais de uma luta que se estabeleceu durante todo o processo de transição e que demandou publicamente a responsabilização das violações aos direitos humanos cometidas na época.

O que se nota, porém, é que, por mais que os conflitos gerados pela repressão, perseguição e aniquilação das guerrilhas modernas no México resultassem em problemas reais para o Estado mexicano e para a elite priista, e fossem a expressão de um regime 
autoritário e violador, a existência e ação de tais movimentos não são analisadas como fatores fundamentais para as mudanças da transição mexicana. Em outras palavras, ao passo que os estudantes de 1968 são os "geradores" da transição, os militantes guerrilheiros ficam excluídos desse processo. Na maioria das interpretações sobre a transição mexicana, portanto, desconsidera-se a participação desses setores radicalizados e quase não é possível identificar a relação direta entre eles e as consequentes transformações ${ }^{17}$.

Nesse sentido, é preciso considerar que o conjunto dos movimentos sociais, desde a década de 1960, além da inegável importância histórica e política atribuída ao movimento estudantil de 1968, foi fator determinante para as mudanças de cunho legal e institucional que propiciaram maiores participações político-partidárias nas décadas seguintes. Inclui-se nesse processo, portanto, o forte questionamento dos setores radicalizados e armados que conformaram as guerrilhas daquele momento e que colocaram em xeque a hegemonia priista, a partir de suas pautas revolucionárias.

Entre avanços e retrocessos, os governos priístas das últimas décadas do século XX protagonizaram ações motivadas pelas pressões sociais, mas também pela necessidade de se manter no poder. Por isso, a chamada "transição democrática", que culmina nas eleições de Vicente Fox em 2000, pode ser caracterizada mais pelas alterações negociadas e pactuadas do que por rupturas estruturais que pudessem assentar mudanças institucionais profundas. A seguir, veremos que esse processo se estende por toda a década de 1990 e envolve outros movimentos sociais na luta pela democratização do sistema político. Tal momento também é marcado pela ampliação de demandas em torno da agenda direitos humanos, reivindicações que foram incorporadas por Vicente Fox na construção de suas campanhas eleitorais.

\footnotetext{
${ }^{17}$ A historiadora Adela Cedillo é uma das poucas intérpretes desse período que destaca a importância do movimento armado moderno na configuração da transição à democracia (2008).
} 


\section{A luta civil pela transição e a vitória de Vicente Fox: os usos do passado recente para a legitimação de um "novo" regime político}

O giro político dado nas eleições presidências de 2000 vai além das transformações na legislação eleitoral, sendo que também encontra seus antecedentes em agrupamentos de cidadãos que demandavam a democratização dos espaços e das representações políticas. Como já abordado, as eleições de 1988 representaram uma derrota para as frentes democráticas mexicanas e serviram como anúncio de que uma transição pela via eleitoral não seria facilmente conquistada. Diante disso, o Partido da Revolução Democrática, criado em 1989, se configurou como uma alternativa à esquerda para ativistas sociais que não queriam participar da polarização política causada pelas disputas entre PRI e PAN. A filiação de ex-guerrilheiros, representantes de movimentos sindicais e uma grande quantidade de militantes pela democracia, fez com que o PRD se transformasse na principal frente de esquerda e de oposição ao sistema político mexicano desde então ${ }^{18}$.

Já na década de 1990, aqueles atores que não participaram dessa filiação em "massa" ao PRD se preocuparam em criar, fora do sistema político, mecanismos e estratégias de pressão social em favor da democracia. Esses novos agentes históricos eram diversificados, e se configuravam desde ONGs, movimentos de jovens atrelados à cultura urbana nas universidades e outros espaços educativos até grupos conservadores alinhados a um catolicismo tradicional (OLVERA, 2010). Como exemplo, podemos citar o caso da ONG Organismos civiles por la democracia, criada em 1990, e o Foro de Apoyo Mutuo, de 1992, ambos com propostas para pressionar as instâncias políticas pela democratização do estado.

Uma dessas iniciativas configura-se justamente como o antecedente direto das transformações vividas pela sociedade mexicana nos anos 2000: a Alianza Cívica. A

\footnotetext{
${ }^{18}$ Em seu programa partidário, o PRD se define como um partido de esquerda que prioriza a "búsqueda de la igualdad o equidad en todos los ámbitos de la vida social humana. (...) Su línea programática se ubica en la transformación pacífica, por la vía electoral, del sistema capitalista y en la búsqueda de un modelo propio de desarrollo y progreso para el conjunto de la sociedad". Disponível em: http://www.prd.org.mx/ (verificado em junho de 2020).
} 
criação dessa frente popular pela democracia acontece depois de inúmeras experiências do mesmo tipo, em diversos lugares do país como o Consejo por la Democracia e o Acuerdo Nacional por la Democracia, ambos na década de 1990. Aos poucos, o crescimento de tais frentes deu origem a um movimento que abarcou cerca de 30 estados do país e cujo principal objetivo era monitorar as eleições e garantir que os resultados não repetissem a fraude de 1988. Assim, em 1994, cerca de 40 mil pessoas acompanharam as contagens de cédulas em 5.000 urnas do país, além das coberturas midiáticas, de possíveis "bocas de urnas" e também os gastos de campanha (OLVERA, 2010, p.191).

As eleições para a presidência daquele ano foram marcadas, no entanto, por extrema violência (VEGA, 1995). Aos conflitos iniciados pela intervenção das Forças Armadas contra o levante do Exército Zapatista de Libertação Nacional (EZLN), em primeiro de janeiro, somam-se o assassinato do candidato priísta à Presidência da República, Luis Donaldo Colosio ${ }^{19}$, e o sequestro de vários empresários.

A Aliança Cívica surge justamente em meio a esse contexto de insegurança nacional e consequente vitória do PRI, ciente de que a alternância política só seria possível com estratégias a médio prazo. As ações encabeçadas a partir de então pela Aliança resultaram na já citada reforma política do Código Federal Eleitoral, institucionalizando plenamente a autonomia jurídica do $\mathrm{IFE}^{20}$, o que permitia eleições mais limpas e menos predispostas a interesses partidários. Além disso, em dita reforma abriu-se espaço para os conselheiros eleitorais cidadãos, que passaram a auxiliar as eleições federais. Por outro lado, ficaram em aberto questões como a tipificação dos delitos federais, a impossibilidade de combater a compra e venda de votos e, de acordo com Alberto Olvera,

\footnotetext{
${ }^{19}$ Depois de mais de vinte anos do assassinato de Luis Donaldo Colosio, ocorrido na cidade fronteiriça de Tijuana, as investigações conduzidas pela Procuradoria Geral da República não suscitaram esclarecimentos sobre os responsáveis e as motivações para o crime. No entanto, a mídia e os organismos de direitos humanos apostam em causas oriundas de disputas internas do próprio PRI, cuja cúpula teria ordenado o assassinato de Colosio, visto que ele era um dos favoráveis a uma reforma interna no partido em nome da democratização de suas práticas e lideranças. Dados e informes da investigação podem ser acessados em: https://www.gob.mx/fgr/documentos/expediente-del-homicidio-del-licenciado-luis-donaldo-colosio-212993 (verificado em junho de 2020)

${ }^{20}$ Até a reforma de 1996, o IFE era um organismo partidário que respondia basicamente aos interesses de manutenção do poder do PRI.
} 
uma das grandes pendências da "interminável transição mexicana" (2010, p. 194): a pouca confiança dos mexicanos em relação aos processos eleitorais ${ }^{21}$.

Esse contexto também está marcado pelas eleições de julho de 1997, que se configuraram no primeiro processo eleitoral no qual os partidos de oposição em conjunto obtiveram a maioria das cadeiras da Câmara dos Deputados (257 contra 243). O candidato do PRD, Cuauhtémoc Cárdenas, venceu as eleições para chefe de governo do Distrito Federal e passou a exercer a oposição na região geográfica, econômica, social e política mais importante do México. Já nos âmbitos estaduais, o PAN venceu as eleições para governador nos estados de Querétaro e Nuevo León (OLVERA, 2010, p.198).

Não obstante, essa conjuntura política que se caracteriza, de acordo com Olvera, por uma "meia transição a democracia", não apresentava de fato os avanços pretendidos pelas ONGs. Ao final da década de 1990, a Aliança Cívica vivia já uma gradual crise interna causada pela dispersão de ativistas que foram paulatinamente absorvidos pelos novos governos de "oposição".

Paralelamente às pressões exercidas pelos grupos cidadãos, o PRI já dava sinais de forte esgotamento quanto às suas estratégias de manutenção da hegemonia política. A cisão entre seus membros ficou ainda mais clara após a matança de Acteal, ocorrida em 1997, no estado de Chiapas, quando paramilitares atacaram indígenas da região e acarretaram a morte de dezenas de pessoas, em sua maioria mulheres e crianças (MONIARDIN, 1999). Ernesto Zedillo (PRI), então Presidente da República, foi acusado por movimentos sociais e organismos de direitos humanos de idealizar a matança. Assim, conforme se aproximava o pleito eleitoral de 2000, o PRI tinha três grandes desafios: desviar-se dos respingos causados pela matança, democratizar seu programa político e lançar um candidato que pudesse incorporar o discurso da mudança. Conformou-se, portanto, uma Comissão para o Desenvolvimento do Processo Interno, que levaria a cabo

\footnotetext{
${ }^{21}$ Em estudo divulgado pela Ong. Observatório Eleitoral Latino-americano, que compara 8 países da América Latina, o México aparece com um dos piores níveis de confiabilidade nas eleições de 1994 (12\%) - perdendo apenas para o Paraguai (9\%) - num processo eleitoral que envolveu efetivamente apenas 3 partidos. A título de comparação com o Brasil, neste o nível de confiabilidade também resultou baixo (23\%) num processo que envolveu 11 partidos políticos (MOLINA e HERNÁNDEZ, 1999).
} 
a votação das mudanças do partido e também para a indicação de um candidato à presidência. O escolhido foi então Francisco Labastida Ochoa ${ }^{22}$.

Quando tudo indicava - inclusive as pesquisas eleitorais - que o PRI conquistaria mais um governo em meio a esse turbilhão de avanços e retrocessos, surgiu a figura de Vicente Fox Quesada ${ }^{23}$. A necessidade de alternância política da presidência, amparada tanto por setores progressistas quanto conservadores, se transformou em terreno fértil para o candidato do Partido Ação Nacional, cujos discursos apoiavam-se na memória dos movimentos sociais e também nas demandas do presente, e cujas promessas iam desde a democratização do sistema político mexicano até a investigação das violações de direitos humanos cometidas por agentes dos governos priistas. Fez-se, assim, o candidato da "alternância política", quem seria visto pelo seu próprio partido e pelos grupos apoiadores de sua candidatura como o "protagonista da transição".

As articulações para a mudança presidencial deram origem a duas grandes alianças partidárias: a Alianza por México, formada pelo PRD e outros partidos ${ }^{24}$, e a Alianza para el Cambio, integrada pelo PAN e pelo Partido Verde Ecologista do México (PVEM). O pleito eleitoral seria marcado, portanto, por uma "tripolarização" partidária (PRI x PAN x PRD) e uma bipolarização de interesses já que tanto o PRD quanto o PAN tinham como principal objetivo colocar fim a setenta e um anos de governos priistas ininterruptos.

Por sua parte, o Partido da Revolução Democrática lançou a candidatura de Cuauhtemóc Cárdenas, o mesmo que havia sofrido com a fraude eleitoral nas eleições de 1988. A escolha de Cárdenas foi resultado de esquemas pouco transparentes, o que provocou conflitos com outro pré-candidato, Porfirio Muñoz Ledo, quem se desligou do partido e se lançou como candidato à presidência pelo PARM (Partido Autêntico da

\footnotetext{
${ }^{22}$ Ao ser escolhido como o candidato do PRI à presidencia, Labastida declarou: "Nosotros demostramos, en los hechos, que somos el partido de la democracia en México; que estamos preparados para triunfar y gobernar en el nuevo siglo. Somos el partido del cambio. [...] Nadie más, tiene esa legitimidad" (AGUAYO, 2011, s/p).

${ }^{23}$ Nas eleições abertas realizadas para a escolha do candidato priísta em novembro de 1999, Labastida venceu em 270 dos 300 distritos eleitorais e conseguiu 55\% dos votos (MARTÍNEZ e PÉREZ, 2001).

${ }^{24}$ Partido del Trabajo (PT), Convergencia Ciudadana (CONV), Partido de la Sociedad Nacionalista (PSN) y Partido Auténtico Socialista (PAS). (REYNOSO, 2010)
} 
Revolução Mexicana). A cisão evidenciava que o discurso de Cárdenas em prol da democracia confrontava-se com as deficiências internas do PRD e a incapacidade do partido de reunir uma esquerda fragmentada e os setores radicais que desconfiavam do processo eleitoral. Durante as campanhas, as lideranças do partido reconheceram a impossibilidade de triunfar nas eleições presidenciais dando mais atenção ao fortalecimento de candidaturas para outros cargos. Tal atitude facilitou as estratégias do PAN e de seus apoiadores em torno do conceito de "voto útil" (AGUAYO, 2011).

Vicente Fox, quem havia iniciado sua campanha eleitoral de forma agressiva em 1998, enquanto ainda era governador de Guanajuato e com a ajuda de um grupo denominado "Los amigos de Fox", conseguiu atrair a simpatia de milhares de eleitores ${ }^{25}$. O candidato foi capaz de superar a complexa dinâmica interna do PAN, gerando insatisfação de setores importantes do partido. No entanto, de acordo com Antonia Martínez e Germán Pérez (2001, p. 283), a estratégia de Fox em agir à margem das determinações do partido, ainda que filiado a ele, serviu para consolidar sua imagem de agente da alternância política frente a uma sociedade que desacreditava das relações políticas tradicionais. Essa estratégia foi beneficiada pela passividade da atuação do PRD durante o pleito eleitoral, o que reforçava a ideia de que o candidato panista era a única alternativa possível para aqueles que sonhavam com a transição.

Durante a campanha eleitoral de 2000, um dos grandes desafios dos candidatos da oposição era articular argumentos que postulassem a necessidade de transformar a sociedade mexicana e o sistema político do país diante de um eleitorado que, de um lado tinha se mostrado conservador a mudanças radicais nas disputas passadas, enquanto de outro, desconfiava dos procedimentos eleitorais tradicionais. Para se destacar em meio a tantas propagandas políticas calcadas em uma mesma bandeira, Vicente Fox se apresentou e foi reconhecido como o "guia condutor da mudança" (BENAVENTE, 2003).

\footnotetext{
${ }^{25}$ Os "amigos de Fox" deveriam atuar a partir da estratégia do "boca a boca", ou seja, o convencimento de possíveis eleitores a partir do engajamento daqueles que acreditavam e podiam informar sobre o projeto político do candidato. Os resultados traduziram-se no levantamento de recursos materiais e econômicos para a campanha e também a disseminação da ideia de que Fox era o candidato idôneo do PAN. Enquanto que em 1998 apenas 18\% dos mexicanos conheciam Fox, no ano seguinte esse número subiu para mais de 70\% (BENAVENTE, 2003, p.106).
} 
A aceitação do candidato era resultado de um rechaço em relação ao PRI, uma indiferença quanto ao candidato do PRD e, de acordo com Adriana Benavente (2003), outros aspectos diversos, como sua origem provinciana, o fato de que ele não provinha de uma família com relações políticas tradicionais, sua carreira de empresário bem sucedido, sua vida privada como pai separado que se encarregou de cuidar dos quatro filhos, e sua figura carismática, católica, e com experiência política. Assim, essa conjunção de fatores atraiu a simpatia de grupos empresariais, religiosos, camponeses e setores da esquerda ${ }^{26}$.

As estratégias de Vicente Fox, no entanto, não se restringiram ao terreno nacional. $\mathrm{O}$ aspirante ao cargo de presidente mexicano fez parte de um grupo que tentou articular, em nível latino-americano, candidaturas alternativas que pudessem ajudar na consolidação da democracia regional e repensar as políticas nacionais para além do neoliberalismo. Os precursores da ação foram Jorge Castañeda - que se tornou conselheiro da campanha presidencial de Fox e posteriormente foi nomeado Ministro das Relações Exteriores de seu governo - e Roberto Mangabeira Unger, que durante os governos Luís Inácio Lula da Silva e Dilma Rousseff assumiu o Ministério de Assuntos Estratégicos. A iniciativa começou em 1996 e reuniu uma série de políticos cujas orientações ideológicas eram consideradas de "centro" e de "esquerda"27.

A inserção de Vicente Fox no grupo consistia em uma das chaves para tornar o então governador de Guanajuato na figura central do processo de "transição democrática" que se propunha para o México (CASTAÑEDA, 2014). Aproximá-lo de uma rede mais ampla de solidariedade também era o caminho para fortalecer a figura do candidato

\footnotetext{
${ }^{26}$ De acordo com Alejandro Moreno (2003, p.183), cerca de 1,8 milhão de votos de esquerda e centroesquerda foram para Fox.

${ }^{27}$ No documento intitulado "Alternativa latinoamericana", publicado integralmente na revista Nexos, Jorge Castañeda e Mangabeira Unger descrevem os objetivos do grupo que deveria desempenhar esforços para redefinir os vínculos da América Latina com a economia mundial, a partir, principalmente, do estreitamento dos laços e das ajudas mútuas a nível regional. Nesse sentido, o documento reforça a necessidade de ir além do âmbito comercial e fortalecer as relações regionais nos campos político e social, fomentando um processo que pudesse estimular o sentimento de pertencimento latino-americano, bem como promover solidariedades e reduzir preconceitos. Além disso, o compromisso pressupunha o fortalecimento da democracia através de um "choque libertário", capaz de reduzir as desigualdades e atender as demandas sociais, criando instituições políticas e econômicas "assentadas em novos modos de vinculação entre democracia representativa e participação cidadã". (CASTAÑEDA e UNGER, 1998).
} 
panista como "agente da transição", bem como conseguir apoio na imprensa internacional quanto à urgência da retirada do PRI do poder. Assim, com um trabalho que se deu nos campos políticos externo e interno, Vicente Fox pode ampliar seu escopo de atuação e conferir maior legitimidade à sua campanha.

A eleição do dia 2 de julho de 2000 deixou milhões de mexicanos e espectadores internacionais na expectativa pelos resultados. Ao final das votações, Vicente Fox venceu com $42,5 \%$ dos votos válidos, enquanto Labastida conquistou 36,1\% e Cárdenas 16,64\% 28 . No entanto, a competitividade que marcou o processo eleitoral fez com que Fox recebesse o menor percentual de votos em comparação às três eleições anteriores, nas quais a média foi de cerca de $57 \%$ dos votos válidos para o PRI ${ }^{29}$. No âmbito legislativo, o PRI continuou como maioria no Senado com a eleição de 60 senadores, seguido pelo PAN e pelo PRD, que conseguiram eleger, respectivamente, 47 e 14 senadores. Na Câmara dos Deputados, o PRI voltou a ser maioria ocupando 239 cadeiras, enquanto que o PAN assumiu 121 lugares. Importante ressaltar a forte presença do PRD, que ocupou 125 cadeiras naquele pleito eleitoral (MARTÍNEZ e PÉREZ, 2001)

Ao tomar conhecimento de que havia vencido um processo eleitoral tão importante para a história mexicana, Vicente Fox fez um discurso que selou sua imagem de agente da transição democrática. "Hoy han hecho historia. El pueblo de México decidió con serenidad y confianza por el cambio" (CASTILLO [et al], 2009, p.103), declarou o recém-eleito presidente. No mesmo discurso, Fox recuperou a memória dos movimentos sociais do passado e congratulou o povo mexicano por ter participado nas urnas e optado pela "alternância pacífica”: “¡Ganó México!”.

(...) El 2 de julio será uno de los grandes días del calendario cívico de México. Lo que hoy vivimos los mexicanos es la culminación de las luchas de varias generaciones, es la culminación de las reformas impulsadas por todos los partidos políticos. Teníamos las mexicanas y los mexicanos una cita pendiente

\footnotetext{
${ }^{28}$ Os dados podem ser confirmados em: http://www.ine.mx/portal/

${ }^{29}$ Por outro lado, as eleições de 2000 também apresentaram alto índice de abstenções (36\% contra $22 \%$ em 1994). Causadas também pela não obrigatoriedade do voto, as abstenções podem ser explicadas pelo distanciamento que alguns grupos conservam em relação aos processos político-eleitorais tradicionais e pela incredulidade na capacidade transformadora do voto individual. (MARTÍNEZ e PÉREZ, p. 291)
} 
con la historia. Hoy cumplimos cabalmente con ese compromiso (...). (CASTILLO [et al], 2009, p.103-105)

Os argumentos que justificavam o giro político histórico ficaram ainda mais claros no discurso de posse de Vicente Fox. Nele, o presidente eleito assumiu a tarefa de democratizar o estado mexicano e criar instrumentos para a inclusão de grupos antes negligenciados pelos governos priistas, tais como os jovens, os indígenas, os camponeses e os idosos. Como forma de se distanciar dos mandatos anteriores e dar legitimidade à sua proposta democrática, Fox relembrou antigos líderes da oposição que foram perseguidos pelo estado, tomando para si o legado de luta desses homens.

(...) Rindo homenaje a los hombres y mujeres que fundaron organizaciones y
partidos políticos, a los que por encima del triunfo personal, creyeron y
enseñaron a creer en el triunfo de un México democrático; a quienes hicieron
de cada esquina una tribuna, hasta obtener este triunfo para la democracia.
Pienso en José Vasconcelos, en Manuel Gómez Morán, en Vicente Lombardo
Toledano, en Valentín Campa, en José Revueltas, en Manuel Clouthier, en
Salvador Nava, en Luis Donaldo Colosio, en Heberto Castillo y en Carlos
Castillo Peraza, entre otros muchos hombres y mujeres de este país. Hombres
de signos políticos diversos, pero de una misma convicción democrática.
Todos ellos estarán -- hoy y siempre -- presentes en nuestra memoria. (...)
(ARCHIVO PRESIDENCIAL, 2000)

Dentre os nomes citados por Fox, estava o do ex-reitor da Unam e ícone da educação no México, José Vasconcelos; membros da esquerda mexicana como o fundador do Partido Popular Socialista (PPS), Vicente Lombardo Toledano; o ex-líder do maior movimento ferroviário do país, Valentín Campa, e Heberto Castillo, engenheiro e professor da UNAM, quem foi duramente perseguido por declarar apoio ao movimento estudantil de 1968. Dessa forma, Fox buscava construir a imagem de um novo presidente cujas propostas levariam em conta a luta pela democratização do Estado desses antigos protagonistas.

Vicente Fox também assumiu a presidência com a promessa de realizar uma grande reforma de Estado contendo sete pontos fundamentais: a criação de instrumentos que consolidassem o "avanço democrático" com objetivo de garantir a participação popular e a liberdade de expressão; combate à pobreza e a desigualdade social; uma reforma educativa; empreender estratégias que garantissem o crescimento econômico 
com estabilidade; descentralização dos recursos e atividades da federação para fortalecer a autonomia dos estados, municípios e comunidades; transparência e prestação de contas, e políticas de combate à insegurança e impunidade. Para cumprir tais objetivos, o novo presidente convocou a todos os partidos políticos, seus membros e sociedade em geral a "esquecerem as diferenças" e trabalharem para um "novo futuro para México" (ARCHIVO PRESIDENCIAL, 2000).

Para consolidar sua imagem de "agente da transição democrática" no país, Vicente Fox não poderia se isentar de rever questões do passado. Por isso, o Presidente também se propôs a "abrir o que permaneceu fechado em episódios sensíveis" da história mexicana. A frase é uma alusão a um compromisso de campanha em abrir os arquivos e criar uma lei de acesso à informação. Sua proposta política em relação ao passado incluía também investigar o que ficou pendente nos governos anteriores, "mediante uma instância que atenda aos pedidos pela verdade da maioria dos mexicanos" (ARCHIVO PRESIDENCIAL, 2000).

Com seu incisivo discurso, Vicente Fox (ao menos na teoria) abria as portas para olhar para o passado e "render contas" com ele. "Não haverá piedoso esquecimento para quem cometeu crimes, tampouco tolerância para quem pretende continuar com privilégios aceitáveis", disse ele. Assim, o novo presidente enchia de novas esperanças aqueles que buscavam a revelação, a investigação e a responsabilização das violações cometidas no passado. Tudo levava a crer que Vicente Fox estava disposto a instalar mecanismos de justiça de transição, empenhados em promover a memória e a justiça, reconciliando a sociedade em um novo período político e para um novo futuro.

\section{Transição de curta duração: o abandono dos compromissos de campanha}

Nos primeiros meses de seu mantado, o presidente Vicente Fox se mostrou comprometido em transformar a imagem do México não só internamente, mas no âmbito internacional. Nesse sentido, empreendeu uma série de medidas importantes em matéria de direitos humanos que representava um primeiro passo para institucionalizar 
mecanismos de justiça transicional e revisar o passado, cumprindo, assim, suas promessas de campanha com organismos de direitos humanos, de familiares de mortos e desaparecidos, bem como vítimas da repressão institucionalizada nos anos anteriores pelo $\mathrm{PRI}^{30}$.

Segundo Emma Calviño (2009), um dos mais importantes atos nesse sentido foi a nomeação da embaixadora especial para os Direitos Humanos e a Democracia da Secretaria de Relações Exteriores, Marie Claire Acosta, uma reconhecida ativista na área. Além disso, nas sessões da Comissão de Direitos Humanos da ONU, em 2001, o então Ministro das Relações Exteriores, Jorge Castañeda anunciou a abertura do México ao escrutínio internacional, formalizando o convite para que observadores internacionais e organizações civis pudessem revisar e analisar os casos pendentes de investigação e responsabilização.

O México também ratificou importantes tratados e convenções internacionais como a Convenção Interamericana sobre Desaparecimento Forçado de Pessoas e a Convenção sobre a Imprescritibilidade dos Crimes de Guerra e dos Crimes de Lesa Humanidade (RIBERTI, 2017, p.210-211). No âmbito internacional, foi um importante aliado das organizações não governamentais e no avanço de medidas de promoção e proteção aos direitos humanos. Calviño (2009, p. 39) destaca a atuação de Vicente Fox na ONU e na OEA, na proposição de várias resoluções que reiteravam o compromisso dos países com esse tema, além de promover convenções e protocolos de prevenção à tortura, ao desaparecimento forçado e de proteção a povos indígenas e de pessoas com necessidades especiais.

Apesar disso tudo, Vicente Fox enfrentava obstáculos políticos para a consolidação de uma de suas principais promessas de campanha: a criação de um mecanismo de justiça de transição que pudesse brindar às vítimas, familiares de mortos e desaparecidos, bem como organismos de direitos humanos as condições para acertar

\footnotetext{
${ }^{30}$ O International Center for Transitional Justice (2009) aponta quatro preceitos que devem nortear o estabelecimento de mecanismos de justiça de transição: investigar, processar e punir os violadores de direitos humanos e tal tarefa está ligada ao direito à justiça da vítima; relevar a verdade para as vítimas, familiares e para a sociedade; reparar e compensar as vítimas, e, por último, afastar os criminosos dos órgãos relacionados ao exercício da lei e de outras posições de autoridade.
} 
contas com o passado. Esses lutadores sociais se empenhavam em fazer atender a demanda pela criação de uma comissão da verdade que pudesse revelar as partes ocultas e silenciadas do passado, discutir amplamente tais questões com a sociedade e priorizar as vítimas e sua reparação no âmbito simbólico e institucional.

De acordo com Sergio Aguayo e Javier Treviño (2007), desde a cúpula governamental, as dificuldades refletiam as tentativas de resolver uma difícil equação que pudesse resultar em um mecanismo capaz de buscar a verdade, outorgar reparações e castigar responsáveis, sem suscitar divergências políticas. No âmbito político, Vicente Fox sofria as pressões dos representantes do legislativo que, no marco da rememoração dos acontecimentos de 2 de outubro, aproveitaram para cobrar o cumprimento da promessa de campanha do novo presidente.

Em princípios de 2001, Fox encarregou a criação de um projeto de comissão da verdade à Adolfo Aguilar Zinser, Sergio Aguayo Quezada, Clara Jusidman e José Antonio Crespo (AGUAYO, 2011). A ideia era criar uma instância de caráter misto, na qual participassem o governo federal e um grupo de cidadãos independentes, com conhecimento sobre o tema dos direitos humanos e designados pelo presidente da república (p. 8789). O projeto apresentado por seus responsáveis ainda pressupunha que a comissão pudesse trabalhar com ampla liberdade e com um mandato "específico, concreto e temporal", além de poder contar com a abertura dos arquivos para suas investigações ${ }^{31}$. De acordo com o documento, a comissão seria dividida em três grupos de trabalho: governamental, corrupção e direitos humanos. O objetivo era que a primeira instância aportasse os documentos e garantisse a autonomia necessária para a condução das investigações pelos outros dois grupos. No cronograma do projeto elaborado consta que os trabalhos da comissão deveriam ser iniciados em setembro de 2001, a partir de um acordo presidencial e da nomeação dos encarregados pelo organismo, e deveriam ser encerrados no final de 2002 com a apresentação dos seus resultados.

\footnotetext{
${ }^{31} \mathrm{O}$ projeto citado faz parte do arquivo pessoal de Adolfo Aguilar Zinser e é reproduzido por Sergio Aguayo em sua obra "La transición en México". O documento completo está disponível no link: http://www.sergioaguayo.org/images/PDF_COLUMNA/Propuesta_de_Comision_de_la_verdad.pdf (verificado em junho de 2020).
} 
Em 12 de junho de 2001, os jornais El Universal e La Jornada publicaram as declarações de Martha Sahagún, então porta-voz da Presidência da República, dizendo que Vicente Fox estava empenhado na criação de uma comissão da verdade (GARDUÑO, 2001). "El presidente Vicente Fox realizará un ajuste de cuentas con el pasado, pero no se hará una "cacería de brujas", a "manera de venganza", sino con el afán de construir un régimen democrático", citou a reportagem do El Universal. (SAAVEDRA, 2001).

$\mathrm{Na}$ mesma edição, o jornal também publicou uma notícia sobre o posicionamento da Comisión Independiente de los Derechos Humanos (CIDH) diante dos casos de desaparecimento de José Ramón García Gómez e o assassinato de um dos líderes guerrilheiros de Guerrero, Rúben Jaramillo, ocorridos durante a “guerra suja”. De acordo com a opinião de José Martínez Cruz, presidente da CIDH, uma comissão da verdade sobre as violações de direitos humanos não poderia ficar restrita a criar uma "narrativa histórica" sobre o passado, mas deveria também investigar e punir os responsáveis. "Para nosotros no puede haber una reconciliación sin justicia; hay delitos de lesa humanidad que carecen de caducidad", declarou Cruz (CABAL, 2001).

Outras notícias publicadas sobre a iminência da criação de uma comissão da verdade refletiram as divergências entre as opiniões, sobretudo no que se referia ao seu caráter investigativo (RIBERTI, 2017, p.134-135). Frente à polêmica, Rafael Macedo de la Concha, Procurador Geral da República na época, declarou que qualquer iniciativa para as investigações de desaparecimento forçado e demais violações de direitos humanos deveriam acontecer dentro dos marcos legais já existentes do país (VARGAS e SALDIERNA, 2001). Sem refutar explicitamente a criação de uma comissão da verdade, o procurador chegou a afirmar que existiam outras instâncias capazes de realizar as investigações demandadas.

Nesse contexto, o debate era travado, sobretudo, com os grupos civis de direitos humanos, já que eram eles os principais defensores de uma comissão da verdade. Na edição de 19 de junho, o jornal El Universal (2001) publicou as versões de Julio Mata Montiel, então secretário executivo da Asociación de Familiares de Desaparecidos Políticos, e de Enrique González Ruiz, presidente da Frente Nacional de Abogados 
Democráticos, defendendo a criação de uma comissão para investigar os casos de desaparecimento forçado no país. Para eles, porta-vozes de familiares de desaparecidos políticos, apenas a tipificação do "desaparecimento forçado" no Código Penal Federal não estabelecia a imprescritibilidade do delito, nem dava conta da gravidade do ilícito que, segundo a ONU, poderia ser equiparado ao crime de genocídio. Além disso, Montiel e Ruíz alegaram que a tipificação do crime de desaparecimento forçado não determinava a impossibilidade dos autores do delito de se beneficiarem do indulto ou da anistia, o que representava uma lacuna na lei. Assim, a criação de uma comissão da verdade poderia assegurar a revisão dos casos para além do âmbito puramente jurídico.

Desde os gabinetes oficiais, no entanto, a discussão parecia ter sido encerrada antes mesmo da entrega do dito projeto encomendado por Vicente Fox. O Secretário de Governo, Santiago Creel, concedeu uma entrevista à revista Proceso (DELGADO, 2001), explicando que era preciso avançar no processo de transição em curso para consolidar a democracia mexicana, e que Vicente Fox também deveria se preocupar com a governabilidade. Admitia que existiam pendências passadas, mas que qualquer revisão deveria ser realizada “con la ley en la mano". Na sua visão, portanto, descartava-se a possibilidade de criação de uma comissão da verdade, debate que, para Creel, estava, inclusive, encerrado.

(...) Podemos lograr una adecuada revisión del pasado con las instituciones de la República. Pongámonos de acuerdo sin escándalos y hagamos de la transparencia una guía de gobierno. No comisiones especiales, no comisiones ad hoc...Si tenemos una Procuraduría (General de la República) de verdad, como la tenemos; si tenemos una Controladuría de verdad, actuante; si tenemos un Congreso de verdad, yo creo que por las instituciones de verdad podemos lograr mucho más que con comisiones que no tengan atribuciones ni competencias ni instrumentos para poder aplicar la ley, para poder ejercer la fuerza coactiva de un Estado (...). (DELGADO, 2001).

Santiago Creel deixou claro, portanto, que o governo de transição não buscava um rompimento com os antigos agentes dos governos anteriores, apontados principalmente pelos organismos civis de direitos humanos como responsáveis, direta e indiretamente, pelas violações de direitos humanos perpetradas nas décadas passadas. Para o governo de transição tornava-se inviável o cumprimento de uma demanda que travasse uma batalha direta com os representantes do PRI no Senado e na Câmara, pois o 
diálogo com tal grupo político era imprescindível para a manutenção da governabilidade e para a aprovação das reformas pretendidas pelo novo presidente (RIBERTI, 2017, p. 143).

Para dissuadir a opinião pública sobre a necessidade de uma comissão da verdade, Creel defendia a falsa capacidade do ordenamento jurídico, político e burocrático do país de lidar com questões complexas e sensíveis, como as demandas pela investigação de desaparecimentos forçados e demais crimes de lesa humanidade.

Ao longo de minhas pesquisas, não pude encontrar nenhuma referência sobre a entrega do projeto de comissão da verdade à Vicente Fox ${ }^{32}$. O documento disponível no site do jornalista Sergio Aguayo, um dos responsáveis pela elaboração do projeto, está datado de 21 de julho ${ }^{33}$. Na imprensa também não houve menção direta de que o presidente havia recebido uma proposta para a elaboração de uma comissão da verdade ${ }^{34}$. A não divulgação oficial desse documento, bem como a inexistência de uma menção explícita sobre ele na imprensa, nos leva a crer que sua discussão e sua elaboração ficaram restritas ao gabinete presidencial.

A disputa protagonizada por importantes personagens desse processo revela que, mesmo diante das petições civis pela criação de uma comissão da verdade, em meados de 2001, os próprios representantes do governo, como Santiago Creel, já descartavam publicamente a possibilidade de estabelecer um organismo desvinculado do governo e que pudesse responder as demandas pela revisão do passado de violações de direitos humanos.

Finalmente, a resposta dada por Vicente Fox à sociedade civil mexicana foi a criação da Fiscalía Especial em novembro de 2001. Naquele contexto, o anúncio da criação de um organismo vinculado à Procuradoria Geral da República foi alvo de uma série de críticas. Além disso, dias antes, as pressões em torno de medidas mais contundentes para garantir os direitos humanos e referendar o compromisso do governo

\footnotetext{
${ }^{32}$ A busca foi realizada nos documentos oficiais do mandato de Vicente Fox, que estão disponíveis em: http://fox.presidencia.gob.mx (verificado em maio de 2017)

${ }^{33}$ Ver em

http://www.sergioaguayo.org/images/PDF_COLUMNA/Propuesta_de_Comision_de_la_verdad.pdf

(verificado em junho de 2002).

${ }^{34}$ Foram verificadas publicações dos jornais La Jornada, El Universal, Reforma e a revista Proceso.
} 
de transição com tal agenda foram intensificadas pelo assassinato Digna Ochoa, ativista do Centro de Derechos Humanos Miguel Agustín Pro Juárez (Centro ProDh) (RIBERTI, 2017, p. 145).

A comoção gerada pelo acontecimento canalizou a urgência de uma resposta de Vicente Fox aos apelos sociais. Convencidos de que esse tipo de assassinato não era um caso isolado, mas sim parte de uma estrutura que permitia a impunidade das violações aos direitos humanos, grupos como Anistia Internacional, Human Rights Watch, juntamente a familiares de mortos e desaparecidos, como Rosario Ibarra Piedra, alçaram suas vozes publicamente para pressionar o atendimento de suas demandas por parte do governo de transição ${ }^{35}$.

Para resolver o impasse, desde seu gabinete, o presidente confrontava-se com três propostas de organismo de justiça de transição (CASTAÑEDA, 2014). A mais conservadora, defendida por Rafael Macedo de la Concha, Procurador Geral da República e pelo secretário de Defesa, general Gerardo Clemente Ricardo Vega García, utilizava o argumento de que se fossem indagadas as identidades dos culpados pelos desaparecimentos, também seria necessário investigar aqueles que causaram as mortes de soldados mexicanos.

Uma proposta mais “ponderada” era defendida por Santiago Creel e o secretário particular de Fox, Alfonso Durazo. Ambos admitiam a necessidade de se realizar alguma investigação, mas que estivesse limitada por um tempo e um espaço, cujo mandato e recursos ficassem sob responsabilidade de um fiscal "aceitável para todos", "assistido por um contingente apropriado de agente do Ministério Público federal para exercer a ação penal se fosse preciso, mas sem entusiasmo diante da perspectiva" (CASTAÑEDA, 2014, s/p). A terceira vertente foi apresentada por Aguilar Zinser e Jorge Castañeda, que defendiam a criação de uma "autêntica" comissão da verdade com capacidades plenas de

\footnotetext{
${ }^{35}$ Rosario Ibarra de Piedra, mãe do guerrilheiro Jesús Piedra Ibarra, desaparecido na década de 1970, foi uma das precursoras do movimento que integrou mães do México todo em busca de seus filhos vítimas de desaparecimento forçado naquele período. Ainda naquela época, Rosario foi uma das articuladoras da criação do Comité Nacional Pro-defensa de Presos, Perseguidos, Desaparecidos y Exiliados Políticos, que depois passou a se chamar Comité Eureka. Em 1982 foi a primeira mulher candidata à presidência da República pelo Partido Revolucionário de los Trabajadores. (CASTELLANOS, 2007)
} 
exercer suas funções autonomamente e cujo mandato consideraria acontecimentos até 1994 e temas como violações aos direitos humanos, crimes de guerra, de lesa humanidade e de corrupção.

O impasse colocara as cartas na mesa: de um lado era imprescindível para o novo presidente manter a governabilidade com setores tradicionais da política a qualquer custo. Por outro, tornou-se impossível conter as pressões de parte do eleitorado que cobrava uma resposta definitiva para um compromisso de campanha. Caso essa demanda não fosse atendida, a legitimidade do governo de "transição" estaria condenada. Para manter o diálogo, Vicente Fox criou um organismo que não atendeu nem questionou nenhum dos lados. A proposta centrista venceu. Nada mais coerente com o signo de seu governo: o centro era o lugar de onde viera, o centro era o lugar no qual ele deveria permanecer para acomodar as divergências.

A decisão, no entanto, representou o abandono de um importante compromisso assumido durante a campanha presidencial e que havia sido responsável por aglutinar setores de esquerda e progressistas na aliança que levou Vicente Fox ao poder. As esperanças de que o novo mandato representaria a ruptura definitiva com os governos anteriores foram, pouco a pouco, morrendo.

Mesmo assim, Vicente Fox tentava manter sua imagem de agente da transição e decretou a criação da Fiscalía com convicção:

(...) Estamos dando un gran paso hacia la consolidación del Estado de Derecho, también estamos sentando las bases para erradicar definitivamente la impunidad en nuestro país. Arrojar luz sobre las partes de nuestro pasado que aún están cubiertas por la oscuridad y hacerlo por la vía institucional, sin ánimos políticos de revanchismo, nos permitirá vernos claramente como una sociedad unida en lo fundamental, nos ayudará a avanzar hacia formas superiores de convivencia, nos servirá para caminar hacia un futuro mejor para todas y para todos. La justicia esperada durante décadas comienza a hacerse realidad (...) (ARCHIVO PRESIDENCIAL, 2001).

Por haver sido resultado de um apelo em nome da governabilidade, a Femospp nasceu desacreditada. Sua criação foi alvo de duras críticas advindas de setores sociais e organismos de direitos humanos que questionavam a eficácia de um organismo que estaria sob a responsabilidade de um órgão comandado por um militar, a Procuradoria 
Geral da República. Nesse sentido, como seria a Fiscalía capaz de avançar com autonomia e imparcialidade nas investigações e na responsabilização dos violadores de direitos humanos, muitos deles membros do exército e das Forças Armadas?

A resposta viria nos anos seguintes. Ao longo de seu mandato, encerrado oficialmente em 2006, a Femospp não foi capaz de responsabilizar nenhum dos acusados por cometerem violações aos direitos humanos, a despeito dos processos iniciados pela sua área de investigação jurídica e das tentativas de enquadramento dos casos em crimes imprescritíveis segundo os tratados internacionais ratificados pelo governo Fox. Sobre o assunto, vale ressaltar que o presidente colocou restrições para a aplicação de tais normas do direito internacional de maneira retroativa, o que se configurou em um entrave jurídico e uma das contradições mais evidentes do governo ${ }^{36}$.

A empolgação de setores de esquerda com a vitória de Fox foi paulatinamente se esvaindo à medida em que o presidente priorizava os acordos em nome da governabilidade, em detrimento de seu compromisso com os grupos que integraram a coalizaram que o elegeu. O progressivo abandono de alguns compromissos fundamentais da época da campanha provou que a tarefa de romper com a cultura política priista, seus mecanismos de cooptação e coerção, bem como a construção de um novo sistema político e de um novo ordenamento capaz de promover e proteger os direitos humanos, não foi priorizada como deveria pelo governo. Assim, o passado recente e as reivindicações que giravam em torno dele por parte de segmentos importantes da sociedade civil foram usados para a legitimação de um novo regime político no México, incompleto e inconcluso (HRW, 2006).

A chegada de Fox ao poder não foi capaz de consolidar a transição ou configurar uma democracia sólida. A tarefa de render contas com o passado segue pendente até os dias de hoje.

\footnotetext{
${ }^{36}$ Uma discussão sobre o caso pode ser vista em RIBERTI, 2017, p. 208-209. 


\section{Referências bibliográficas}

AGUAYO Sergio, La charola: una historia de los cuerpos de inteligencia en México, Grijalbo, 2001.

.La transición en México. Una historia documental 1910-2010.

Versión electrónica. México: Fondo de Cultura Económica, 2011.

; RANGEL, Javier Treviño. "Fox y el pasado. La anatomía de una capitulación”. Foro internacional, p. 709-739, 2007.

ARCHIVO PRESIDENCIAL. Versión estenográfica del mensaje del licenciado Vicente Fox Quesada, durante la Sesión Solemne del H. Congreso de la Unión, luego de rendir la Protesta de Ley como Presidente Constitucional de los Estados Unidos Mexicanos. México: 01 de dezembro de 2000.

ARCHIVO PRESIDENCIAL. Versión estenográfica de las palabras del Presidente Vicente Fox Quesada, durante la presentación del Informe y Recomendación de la Comisión Nacional de los Derechos Humanos sobre los Desaparecidos en los años 70 y principios de los 80. México: 27 de novembro de 2001.

BALBUENA SERRANO, C. Comparación de dos Sistemas de Representación Proporcional Mixto: el Caso de México y Alemania. Tesis Licenciatura. Relaciones Internacionales. Departamento de Relaciones Internacionales e Historia, Escuela de Ciencias Sociales, Universidad de las Américas Puebla, 2005.

BALLINAS, Victor. "Comisión de la verdad, sólo mediante consulta". La Jornada. México: 11 de junho de 2001. Disponível em: http://www.jornada.unam.mx/2001/06/11/005n1pol.html (verificado em junho de 2020).

BENAVENTE, Adriana Borjas. "La campaña presidencial de Vicente Fox y el modelo propagandista de comunicación política". América Latina Hoy, 33, 2003, pp. 101-121.

CABAL, Alfonso Cortés. "Proponen ajuste de cuentas em casos José Ramón García Gómez y Rúben Jaramillo”. El Universal. México: 12 de junho de 2001.

CALVIÑO, Emma Consuelo Maza. Derechos humanos: México, retórica sin compromiso. Flacso México, 2009.

CAMÍN, Hector Aguilar e MEYER, Lorenzo. À sombra da Revolução Mexicana. São Paulo: Edusp, 2000.

CASTAÑEDA, Jorge G. Amarres perros. Una autobiografia. México: Alfaguara, 2014. Versão eletrônica. 
CASTAÑEDA, Jorge e UNGER, Roberto Mangabeira. "Después del neoliberalismo: Un Nuevo Camino". Revista Nexos, 01 de março de 1998. Disponível no link: http://www.nexos.com.mx/?p=8825 (verificado em junho de 2020).

CASTELLANOS, Laura. México armado 1943-1981. Ediciones Era, 2007.

CASTILLO, Germán Perez Fernández, CISNEROS, Arnulfo Puga, SANTANA, Héctor (comp.). Memoria histórica de la transición democrática en México, 1977-2007. Documentos básicos para entender el cambio político. México: Ángel Porrúa, 2009, Tomo. III, p. 103.

CEDILLO, Adela. El fuego y el silencio. Historia de las FLP. Série "México: Genocídio y delitos de lesa humanidad: Documentos Fundamentales 1968-2008”. México: 2008. Tomo VIII.

Centro de Derechos Humanos "Miguel Agustín Pro Juárez". Informe Derechos incumplidos, violaciones legalizadas: Los derechos humanos en el sexenio 2000-2006. México, 2006. Disponível em: http://centroprodh.org.mx/

Centro de Investigaciones Históricas de los Movimientos Sociales A.C. La Verdad Negada. México: 2012.

Comisión de Derechos Humanos del Distrito Federal (Comp); Memoria do "Seminario internacional Comisiones de la verdad: Tortura, reparación y prevención.". "Foro público Comisiones de la verdad: Perspectivas y alcances El caso de México. México: 2004.

Comité 68 Pró Libertades Democráticas. Denuncia y criterios del Comité 68: Las imputaciones a los genocidios. Serie México: Genocidio y delitos de lesa humanidad: Documentos fundamentales (1968-2008). México, 2008.

Comité 68, Centro Prodh (Orgs). [et.al.]. Esclarecimiento y sanción a los delitos del pasado en el sexenio 2000 - 2006: Compromisos quebrantados y justicia aplazada.

DELGADO, Álvaro e GUTIÉRREZ, Alejandro. "Revisión del pasado, con la ley en la mano: Creel". Proceso. México, 16 de junho de 2001, n. 1285.

EL UNIVERSAL. "Piden familiares de desaparecidos políticos crear Comisión de la Verdad". México: 19 de junho de 2001.

FAVELA, Margarita. "Sistema político y protesta social: del autoritarismo a la pluralidad”. BIZBERG, Ilán; ZAPATA, Francisco (Coord). Movimientos sociales. In. 
ORDORICAY, Manuel; PRUD'HOMME, Jean-François (coord.). Los grandes problemas de México. México, D.F. : El Colegio de México, 2010, v. 6,

FISCALÍA ESPECIAL PARA MOVIMIENTOS SOCIALES Y POLÍTICOS DEL PASADO. Informe Histórico Presentado A La Sociedad Mexicana. Série "México: Genocídio y delitos de lesa humanidad: Documentos Fundamentales 1968-2008". México: 2008. Tomo IX.

Francisco Gómez y Silvia Otero. "Echeverría, bajo prisión preventiva domiciliaria”. El Universal. Sábado 01 de julio de 2006.

FRANCO, Marina \& LEVÍN, Florencia. "El pasado cercano en clave historiográfica”. In: FRANCO, Marina \& LEVÍN, Florencia. Historia reciente: perspectivas y desafíos para un campo en construcción. Buenos Aires: Paidós, 2007.

GARCÍA, Julio Scherer \& MONSIVÁIS, Carlos. Parte de Guerra: Tlatelolco 1968. Documentos del general Marcelino García Barragán. Los hechos y la historia. México: Aguilar, 1999.

GARDUÑO, Roberto. “Creará el gobierno comisión de la verdad: Martha Sahagún”. La Jornada. México: 12 de junho de 2001. Disponível em: http://www.jornada.unam.mx/2001/06/12/008n1pol.html (verificado em junho de 2020).

GÓMEZ, Pablo. 1968: la historia también está hecha de derrotas. Ed. Miguel Ángel Porrúa. México, 2008.

A medio camino. A la memoria de Raúl Álvarez Garín. 2 de outubro de 2014. Disponível em: http://pablogomez.org/wordpress1/?p=276 (verificado em junho de 2020).

GONZÁLEZ, Victor Hugo Martínez. Fisiones y fusiones, divorcios y reconciliaciones. La dirigencia del Partido de la Revolución Democrática (PRD), 1989-2004. México: Plaza y Valdéz, 2005.

HUMAN RIGHTS WATCH (HRW). El Cambio Inconcluso. Avances y desaciertos en derechos humanos durante el gobierno de Fox. Mayo de 2006.

INTERNATIONAL CENTER FOR TRANSITIONAL JUSTICE. What is Transitional Justice?, 2009. Disponível em: https://www.ictj.org/about/transitional-justice (verificado em junho de 2020).

LOAEZA, Soledad. "México 1968: los orígenes de la transición”. Foro Internacional. Vol. 30, No. 1 (117) (Jul. - Sep., 1989), pp. 66-92. 
MARTÍNEZ, Antonia e PÉREZ, Germán. "Transición democrática y elecciones en México". Revista de Estudios Políticos (Nueva Época), n.112, abril-junio 2001.

MEYER, Lorenzo. Fin del régimen, democracia incipiente: México hacia fines del siglo XX. México, Editorial Océano, 1998.

MEYER, Lorenzo. "La guerra fría en el mundo periférico: el caso del régimen autoritario mexicano. La utilidad del anticomunismo discreto". Espejos de la guerra fría: México, América Central y el Caribe, p. 95-117, 2004.

MEZAROBBA, Glenda. "De que se fala, quando se diz justiça de transição?". Assy, Bethania [et al], Direitos Humanos: justiça, verdade e memória. Rio de Janeiro: Lumen Juris, 2012.

MOLINA, José; HERNÁNDEZ, Janeth, "La credibilidad de las elecciones latinoamericanas y sus factores. El efecto de los organismos electorales, el sistema de partidos y las actitudes políticas.”. Cuadernos del Cendes 41, mayo-agosto 1999, pp. 126.

MONIARDIN, Adriana López. "Los acuerdos de San Andrés y los gobiernos autónomos en Chiapas”. Espiral, Estudios sobre Estado y Sociedad. Vol, V, N. 14, México, 1999.

MONSIVAIS, Carlos (org.). La transición interrumpida: México 1968-1988. México: Universidad Iberoamericana, 1993.

MONTAÑO; Eugenia Allier. Presentes-pasados del 68 mexicano. Una historización de las memorias públicas del movimiento estudiantil, 1968-2007. Revista Mexicana de Sociologia, 71, n.02 (abril-junho, 2009).

MONTEMAYOR, Carlos. Chiapas: la rebelión indígena de México. México: Espasa Calpe, 1998.

MORENO, Alejandro. El votante mexicano: democracia, actitudes políticas y conducta electoral. México: FCE, 2003, p.183.

MUÑOZ, Rodolfo Gamiño. Guerrilla, represión y prensa en la década de los setenta en México. México: Instituto de Investigaciones Dr. José María Luis Mora, 2012.

NIEBLA, Gilberto Guevara. 1968. Largo camino a la democracia. México: Cal y Arena, 2008 .

OLVERA, Alberto. "De la sociedad civil política y los límites y posibilidades de la política de la sociedad civil: el caso de Alianza Cívica y la transición democrática en México". BIZBERG, Ilán; ZAPATA, Francisco (Coord). Movimientos sociales. In. ORDORICAY, Manuel; PRUD'HOMME, Jean-François (coord.). Colección Los 
grandes problemas de México. México, D.F: El Colegio de México, 2010, v. 6, p 181226.

RAMIREZ, Adriana Sanchez. O processo de transição democrática no México: o papel das reformas eleitorais, a reforma de 1996 e a participação dos grupos civis pródemocráticos. Dissertação de mestrado. Campinas: Universidade Estadual de Campinas, 2002.

REÁTEGUI, Félix (org.). Justiça de transição: manual para a América Latina. Brasíl: Comissão da Anistia, Ministério da Justiça; Nova Iorque: Centro Internacional para a Justiça de Transição, 2011

REYNA, José Luis. "México: una democracia incipiente". En los intersticios de la democracia y el autoritarismo. Algunos casos de Asia, África y América Latina. Cornejo, Romer. cLACSO, Consejo Latinoamericano de Ciencias Sociales, Buenos Aires. Octubre 2006.

REYNOSO, Diego. "Alianzas electorales y contingentes legislativos en los estados mexicanos (1988-2006)". Revista Mexicana de Sociología, 72, núm. 1., p. 113-139. México, enero-marzo, 2010.

RIBERTI, Larissa Jacheta. Entre gritos e granadeiros: a memória do movimento estudantil e do massacre de 1968 no México. Dissertação de mestrado. Rio de Janeiro: Programa de Pós Graduação em História Social da UFRJ, 2013.

Justiça de transição no México: as investigações jurídicas e

o Informe Histórico da Fiscalía Especial para Movimientos Sociales y Políticos del Pasado (2001-2006). Tese de doutorado. Rio de Janeiro: Programa de Pós Graduação em História Social da UFRJ, 2017.

SAAVEDRA, Fabiola Guarneros. "Se trabaja para crear comisión de la verdad, dice Sahagún". El Universal. México: 12 de junho de 2001.

SALAS, Federico (2002). "Democracia y derechos humanos como política exterior" in Rafael Fernández de Castro (ed.) México en el mundo: Cambio y continuidad en la política exterior de México. México: Editorial Planeta, pp. 163-172.

TORRES, Antonio Faustino. "El régimen de partido hegemónico y las reformas electorales en México (1946-1996)". Gaceta de Ciencia Política. México, año 9, n.2, 2012. Disponível em: http://issuu.com/gacetacpol/docs/gaceta9.2 (verificado em junho de 2020)

TREVIÑO-RANGEL, Javier. "Gobernando el pasado: el proceso de justicia transicional en México, 2001-2006”. Foro internacional. México, El Colegio de México, Centro de 
Estudios Internacionales: volumen 54, número 1 (215), (enero-marzo, 2014), páginas 3175 .

VALENZUELA, Luis Arriaga. "Crímenes de Estado y derechos humanos en México." In. Revista El Cotidiano, n. 150. Julio-Agosto de 2008, ano 23.

VARGAS, Rosa e SALDIERNA, Georgina. "Comisión de la verdad, con base jurídica: Macedo”. La Jornada. México: 13 de junho de 2001.

VEGA, María Eugenia Valdés. "Alianza Cívica en las elecciones de 1994. Una reflexión”. Política y Cultura, núm. 5, otoño, 1995, pp. 175-190, Universidad Autónoma Metropolitana Unidad Xochimilco México.

VENTURA, Brisa Maya Solís. "La construcción de las políticas públicas en derechos humanos en México: El Programa Nacional de Derechos Humanos". In. In. Revista El Cotidiano, n. 150. Julio-Agosto de 2008, ano 23.

VICENTE OVALLE, Camilo. Tiempo suspendido: una historia de la desaparición forzada en México, 1940-1980. México: Bonilla Artigas, 2019.

VOCERO. "Movimiento estudiantil de 1968 marcó inicio de la transición democrática: Barbosa." México: 28 de setembro de 2013. Disponível em: http://www.vocero.com.mx/politica_y_polemica/movimiento-estudiantil-de-1968marco-inicio-de-la-transicion-democratica-barbosa/ (verificado em junho de 2020).

WOLDENBERG, José. Historia mínima de la transición democrática en México. México: El Colegio de México, 2012. 